\title{
Risk factors for the increasing trend in low birth weight among live births born by vaginal delivery, Brazil
}

Fatores de risco para a tendência ascendente do baixo peso ao nascer em nascidos vivos de parto vaginal no Sudeste do Brasil

\section{Marco A Barbieria, Antônio AM Silvab, Heloisa Bettiola and Uilho A Gomes}

aD epartamento de Puericultura e Pediatria da Faculdade de Medicina de Ribeirão Preto. Universidade de São Paulo. Ribeirão Preto, SP, Brasil. ' ${ }^{\circ}$ epartamento de Saúde Pública da U niversidade Federal do Maranhão. São Luís, MA, Brasil. 'D epartamento de M edicina Social da Faculdade de Medicina de Ribeirão Preto. U niversidade de São Paulo. Ribeirão Preto, SP, Brasil 


\title{
Risk factors for the increasing trend in low birth weight among live births born by vaginal delivery, Brazil* Fatores de risco para a tendência ascendente do baixo peso ao nascer em nascidos vivos de parto vaginal no Sudeste do Brasil
}

\author{
Marco A Barbieria, Antônio AM Silva ${ }^{b}$, Heloisa Bettiola and U ilho A Gomesc \\ aD epartamento de Puericultura e Pediatria da Faculdade de Medicina de Ribeirão Preto. Universidade \\ de São Paulo. Ribeirão Preto, SP, Brasil. ' $D$ epartamento de Saúde Pública da U niversidade Federal do \\ Maranhão. São Luís, M A, Brasil. 'D epartamento de Medicina Social da Faculdade de M edicina de \\ Ribeirão Preto. Universidade de São Paulo. Ribeirão Preto, SP, Brasil
}

\section{Keywords}

Infant, low birth weight". Infant premature". Labor". Cesarean section\#. Socioeconomic factors. Risk factors. Marital status. Diagnosis of health situation in specific groups. - Preterm birth. Vaginal delivery.

\begin{abstract}
Objective

To identify risk factors for low birth weight (LBW) among live births by vaginal delivery and to determine if the disappearance of the association between LBW and socioeconomic factors was due to confounding by cesarean section.

Methods

Data were obtained from two population-based cohorts of singleton live births in Ribeirão Preto, Southeastern Brazil. The first one comprised 4,698 newborns from June 1978 to May 1979 and the second included 1,399 infants born from May to August 1994. The risks for LBW were tested in a logistic model, including the interaction of the year of survey and all independent variables under analysis.

Results

The incidence of LBW among vaginal deliveries increased from 7.8\% in 197879 to $10 \%$ in 1994 . The risk was higher for: female or preterm infants; newborns of non-cohabiting mothers; newborns whose mothers had fewer prenatal visits or few years of education; first-born infants; and those who had smoking mothers. The interaction of the year of survey with gestational age indicated that the risk of LBW among preterm infants fell from 17.75 to 8.71 in 15 years. The mean birth weight decreased more significantly among newborns from qualified families, who also had the highest increase in preterm birth and non-cohabitation. Conclusions

LBW among vaginal deliveries increased mainly due to a rise in the proportion of preterm births and non-cohabiting mothers. The association between cesarean section and LBW tended to cover up socioeconomic differences in the likelihood of LBW. When vaginal deliveries were analyzed independently, these socioeconomic differences come up again.
\end{abstract}

Correspondence to:

Heloisa Bettiol

Departamento de Puericultura e Pediatria Faculdade de Medicina de Ribeirão Preto Universidade de São Paulo.

Avenida Bandeirantes, 3.900

14049-900 Ribeirão Preto, SP, Brazil

E-mail: hbettiol@fmrp.usp.br
* Supported financially by CNPq (Conselho Nacional de Desenvolvimento Científico e Tecnológico) and Fapesp (Fundação de Amparo à Pesquisa do Estado de São Paulo - Process n 93/0525-0).

The publication of this article was subsidied by Fapesp (Process no 00/01601-8).

Submitted on 8/10/1999. Reviewed on 18/7/2000. Approved on 28/8/2000. 


\section{Descritores}

Baixo peso ao nascer ${ }^{\#}$. Prematuros ${ }^{\#}$. Trabalho de parto ${ }^{\#}$. Cesárea $a^{\#}$.Fatores socioeconômicos. Fatores de risco. Estado civil. Diagnóstico da situação de saúde em grupos específicos. - Nascimento pré-termo. Parto vaginal.

\section{Resumo}

\section{Objetivo}

Identificar fatores de risco para o baixo peso ao nascer (BPN) entre nascidos vivos de parto vaginal e verificar se o desaparecimento da associação entre BPN e fatores socioeconômicos foi devido ao confundimento pela cesariana.

\section{Métodos}

Foram estudadas duas coortes de base populacional de recém-nascidos únicos de parto vaginal em Ribeirão Preto, Sudeste do Brasil. A primeira incluiu 4.698 crianças nascidas entre junho de 1978 e maio de 1979 e a segunda 1.399 crianças nascidas entre maio e agosto de 1994. Os riscos de BPN foram testados num modelo de regressão logística, incluindo interações entre ano da pesquisa e todas as variáveis independentes em análise.

\section{Resultados}

A incidência de BPN entre partos vaginais aumentou de 7,8\% em 1978/79 para 10\% em 1994 para crianças do sexo feminino, para os primogênitos, para nascidos de mães sem companheiro, para nascidos de mães que fizeram menor número de consultas pré-natais ou com menos anos de estudo e para nascidos de mães fumantes. A interação entre ano do parto e idade gestacional indicou que o risco de BPN entre os nascidos prematuros caiu de 17,8 para 8,7 em 15 anos. A média do peso ao nascer reduziu-se mais entre os filhos de famílias mais qualificadas, que tiveram o maior aumento nos nascimentos pré-termo e nas mães sem companheiro.

\section{Conclusões}

O BPN entre partos vaginais aumentou principalmente devido ao incremento nos nascimentos pré-termo e nas mães sem companheiro. A associação entre cesariana e BPN tendeu a encobrir as diferenças socioeconômicas na probabilidade do BPN. $\mathrm{Na}$ análise dos partos vaginais isoladamente, as diferenças socioeconômicas reapareceram.

\section{INTRO DUCTION}

Low birth weight (LBW) is the main factor determining neonatal and perinatal survival and it is also associated with many adverse outcomes in newborns (Kramer, ${ }^{10}$ 1987). In recent years, it has been shown that the LBW rate has decreased in many parts of the world due to improvements in health care and improving life standards (Chike-Obi et al, ${ }^{6} 1996$ ).

In contrast, the LBW rate has increased in some cities of Brazil in the last years. In Pelotas, Southern Brazil, there was an increase from 9\% in 1982 to $9.8 \%$ in 1993 (Horta et al, ${ }^{9}$ 1996).

In previous studies, it was shown an increase in the LBW rate in Ribeirão Preto, Southeastern Brazil, from $7.2 \%$ in $1978-79$ to $10.6 \%$ in 1994 and a rise in the preterm birth rate from $7.6 \%$ in $1978-79$ to $13.6 \%$ in 1994. These changes occurred despite improvements in many risk factors associated with LBW and preterm birth (Silva et al, ${ }^{15}$ 1998; Bettiol et al, ${ }^{4}$ 1999).

Three main factors were found to be associated with the increase in LBW rate: preterm birth, maternal smoking and cesarean section delivery (Silva et al, ${ }^{15}$ 1998). Socioeconomic differences in the risk of LBW were attenuated. The increase in the cesarean section delivery rate explains only partially the increasing trend seen for LBW rate. To explore these relationships, to avoid confounding due to cesarean section, a restricted analysis of risk factors for LBW among live births by vaginal delivery was conducted, since the likelihood of cesarean section was greater for better-off families. The purpose was to analyze risk factors for LBW among vaginal deliveries and to verify if socioeconomic differences really decreased or if they artificially disappeared due to confounders.

\section{METHODS}

Ribeirão Preto is a regional center in the Northeastern region of the State of S. Paulo, Brazil. Its per capita income is one of the highest in the country, about US\$ 5,800 per year. The main economic activities in the region are sugar cane industry, trading, services and financing. The urban population was 461,427 inhabitants in 1994, increasing by $45 \%$ in the last 15 years (Barbieri et al, ${ }^{2}$ 1989; Bettiol et al, ${ }^{3}$ 1998).

From 1978 on, at least $98 \%$ of all births in the city took place in maternity hospitals (Barbieri et al, ${ }^{2}$ 1989). Two surveys were carried out in the maternity hospitals in 1978-79 and 1994. The 1978-79 survey 
started in June 1978 and ended in May 1979 (6,750 births). The 1994 one was a four-month survey, including infants born from May to August $(2,846$ births). The analysis was restricted only to singleton live births by vaginal delivery for families residing in the municipality (4,698 deliveries in 1978-79 and 1,399 in 1994) to avoid selection bias and potential confounding due to multiple gestations. Mothers were interviewed soon after delivery using a standardized questionnaire after their consent. Trained personnel obtained newborn weights using weekly-calibrated scales with 10-g precision. Newborns were weighed naked immediately after delivery. Non-response due both to early hospital discharge and mother's refusal was low $(3.5 \%$ in the first survey and $4.2 \%$ in the second). The method was the same in both surveys and details are described elsewhere (Barbieri et al, ${ }^{2}$ 1989; Bettiol et al, ${ }^{3}$ 1998).

The variables included in the analyses were: birth weight (less than 2,500 g; 2,500 $\mathrm{g}$ and over), newborn gender (male; female), maternal age in years (less than 20; 20 to 34; 35 and over), marital status (cohabiting; non-cohabiting), maternal schooling in years (less than 4; 4 to $11 ; 12$ and over), parity including the current delivery ( $1 ; 2$ to $4 ; 5$ and over), maternal smoking (yes, if the mother had smoked at least one cigarette during pregnancy; no otherwise), family income in minimum wages (less than 4; 4 to 10; 10 and more), preterm birth (yes for less than 37 weeks of gestation; no otherwise), number of prenatal care visits (less than 4; 4 and more), type of insurance (public - those covered by social security or seen at public institutions; private - those who had a private prepaid health care plan or paid for services). A missing category was included for those variables with a large amount of unknown information. Gestational age was calculated according to the last menstrual period. Cases whose birth weight was above the $99^{\text {th }}$ percentile for a given gestational age based on the British nomograms were excluded from the analysis because they were probably mistakenly considered as preterm births (Altman \& Coles, ${ }^{1} 1980$ ). The occupation group of the head of household was drawn from an adaptation of the International Standard Classification of Occupations - ISCO-68 (Bettiol et al, ${ }^{4}$ 1999) and it was considered as a proxy for socioeconomic status and grouped into three categories: non-manual workers, skilled/semi-skilled workers and unskilled workers. Parental occupation was used in the coding of occupational group in most cases. When parental occupation was not recorded, especially for non-cohabiting women, maternal occupation was used instead.

Student's t-test was used to make a comparison between the two surveys' mean birth weight according to occupational groups, and the chi-square test was used when comparing characteristics of the two cohorts. Unadjusted and adjusted odds ratios were obtained by logistic regression using the Stata package. The group at lowest risk of LBW was used as a reference category. A complete model was fitted to include all determinants under analysis, the year of survey and a series of interaction terms between the year of survey and all potential risk factors. These interaction terms served to identify variations in the odds ratio between surveys. Backward elimination was used to fit the final reduced model. In addition, a crude model with the year of survey and a series of sequential models, including one by one all variables associated with LBW in the former model, were fitted. The aim was to identify variables influencing the odds ratio for the year of survey that may be responsible for the increasing trend in LBW among vaginal deliveries.

\section{RESU LTS}

\section{LBW rate and type of delivery}

The LBW rate in 1978-79 was higher for live births by vaginal delivery $(7.8 \%)$ compared to those infants whose mothers underwent cesarean section (5.9\%). This pattern has changed in 1994: the LBW rate was higher for live births whose mothers underwent cesarean section (11.3\%) than for those whose mothers had vaginal delivery $(10.0 \%)$. The rate of increase in the LBW rate was higher for cesarean section $(86.4 \%)$ than for vaginal delivery $(32 \%)$.

The birth weights of infants born by cesarean section were much lower for the 1994 cohort compared to the 1978-79 one. The percentage of those born by cesarean section weighing less than 3,000 grams increased sharply. Although the birth weights of infants whose mothers had vaginal delivery were also reduced, this happened in a slower manner (Figure). The increasing trend in the LBW rate was restricted to the $36^{\text {th }}$ and $37^{\text {th }}$ weeks of gestational age.

The mean birth weight was reduced for all occupational groups (Table 1). The decrease was more marked among infants of better qualified families (-199 grams) than among infants of less qualified families (-97 grams). Social differences in LBW rate decreased due to the higher proportional drop rise among newborns of better qualified families.

\section{Trends in childbearing population characteristics between 1978-79 and 1994}

Some favorable trends were observed among this selected cohort of mothers who had vaginal delivery. 

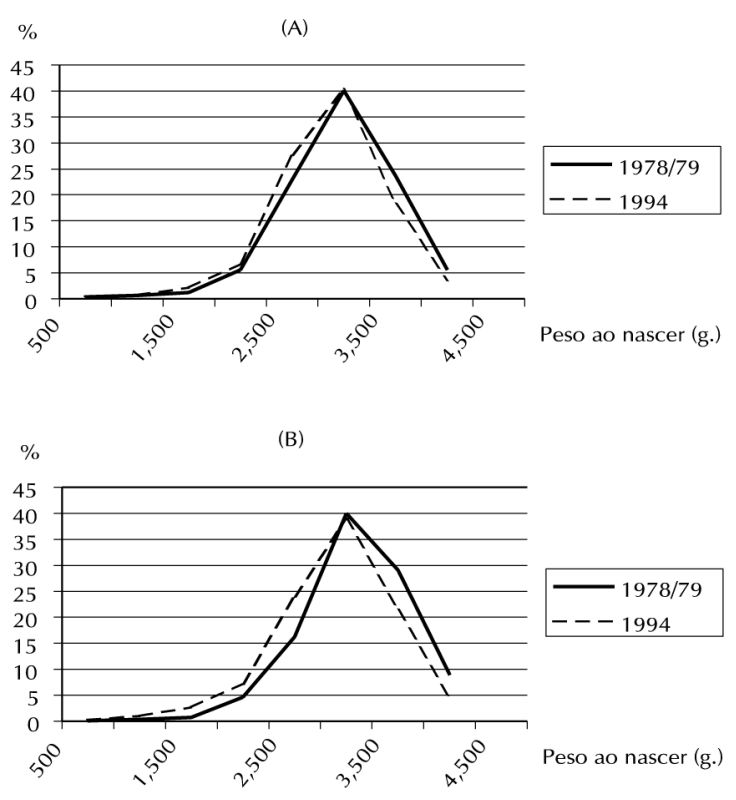

Figure - Distribution of birth weights among singleton live births from vaginal $(A)$ and caesarean delivery (B) in Ribeirão Preto, 1978/79 and 1994.

In 1994 more women had private insurance and a higher family income; they also had a higher number of prenatal visits than 15 years ago and there was a decrease in the percentage of multiparous mothers. The percentage of smoking mothers decreased from $30.3 \%$ to $19.9 \%$. (Table 2 ).

In contrast, the percentage of people in non-manual occupations and the percentage of mothers with 12 or more years of schooling decreased. Three known risk factors for LBW have arisen: the percentage of young mothers (from $16.1 \%$ to $23.0 \%$ ), percentage of noncohabiting mothers, which almost doubled from $7.6 \%$ to $14.8 \%$; and the preterm birth rate among vaginal deliveries, which increased markedly from $8.6 \%$ to $13.9 \%$, a $62 \%$ rise (Table 2).

\section{Risk factors for LBW among women who had vaginal delivery}

The adjusted risk of LBW was higher for female infants and live births of non-cohabiting mothers. It was also higher for those infants whose mothers had less than four prenatal visits, first-births, those newborns whose mothers had less than 12 years of schooling and had smoking mothers (Table 3). There was an interaction between the year of survey and gestational age, indicating that the risk of LBW for those prematurely born fell from 17.75 (95\% CI\% 12.98-24.88) in 1978-79 to 8.71 (95\% CI 5.43-13.95) in 1994. Since mothers of prematurely born infants tend to have fewer prenatal visits, the number of visits was excluded from the model to verify whether this inherent bias may have affected the estimates. As there was no change in the associations described above, the model with the number of prenatal visits was used in the study.

\section{Identification of factors probably associated with the increasing $\mathrm{LBW}$ rate}

Table 4 shows the crude and sequentially adjusted year effect for LBW among vaginal deliveries. The crude odds ratio for LBW comparing 1994 with 197879 (1.32) indicated that the risk of LBW was 32\% higher in 1994. When adjusted also for preterm birth, the risk of LBW for the 1994 cohort was smaller (1.14) and no longer statistically significant, showing that preterm birth was the main contributing factor to this increase. When non-cohabiting status was taken into account, the risk of LBW for 1994 was also reduced from 1.37 to 1.32 , suggesting that non-cohabiting status might have also played a role in this increasing trend. The year effect for LBW in 1994 was higher or unchanged when adjusted for other factors. For example, when the risk of LBW was adjusted at the same time for the year effect, preterm birth and maternal smoking, it was 1.37 , i.e., higher than 1.14 , indicating that maternal smoking had contributed to lower the LBW rate.

\section{DISCUSSION}

It was shown in a previous study that the increase in the cesarean section delivery rate was the factor more closely associated with the increase in LBW rate in Ribeirão Preto along with gestational age and maternal smoking (Silva et al, ${ }^{15}$ 1998). In this study it

Table 1- Mean birth weight (grams) of infants from mothers who had vaginal delivery, according to occupational group. Ribeirão Preto, $1978 / 79$ and 1994.

\begin{tabular}{|c|c|c|c|c|}
\hline Occupational group & $\begin{array}{c}1978 / 79 \\
\text { Mean (sd)* }\end{array}$ & $\begin{array}{c}1994 \\
\text { Mean (sd)* }\end{array}$ & Difference & P-value** \\
\hline $\begin{array}{l}\text { Lower managers, executive and academic jobs } \\
\text { Skilled and semi-skilled } \\
\text { Unskilled/unemployed } \\
\text { All groups }\end{array}$ & $\begin{array}{l}3,333(506) \\
3,196(535) \\
3,159(530) \\
3,198(545)\end{array}$ & $\begin{array}{l}3,134(453) \\
3,102(563) \\
3,062(541) \\
3,097(542)\end{array}$ & $\begin{array}{r}-199 \\
-94 \\
-97 \\
-101\end{array}$ & $\begin{array}{r}<0.001 \\
<0.001 \\
0.002 \\
<0.001\end{array}$ \\
\hline
\end{tabular}

*Figures in parenthesis represent the standard deviation

$* * P$-value for the difference between surveys (Student's t-test) 
Table 2 - Trends in selected population characteristics among vaginal deliveries in singleton livebirths in Ribeirão Preto, Brazil, $1978 / 79$ and 1994.

\begin{tabular}{|c|c|c|c|c|c|}
\hline \multirow[t]{2}{*}{ Variables } & \multicolumn{2}{|c|}{$1978 / 79$} & \multicolumn{2}{|c|}{1994} & \multirow[t]{2}{*}{ P-value* } \\
\hline & $\mathrm{n}$ & $\%$ & $\mathrm{n}$ & $\%$ & \\
\hline \multicolumn{6}{|l|}{ Gender } \\
\hline Male & 2,404 & 51.2 & 705 & 50.4 & \multirow[t]{2}{*}{0.816} \\
\hline $\begin{array}{l}\text { Female } \\
\text { Not known }\end{array}$ & $\begin{array}{r}2,289 \\
5\end{array}$ & $\begin{array}{l}48.8 \\
(0.1)\end{array}$ & $\begin{array}{r}693 \\
1\end{array}$ & $\begin{array}{c}49.6 \\
(0.0)\end{array}$ & \\
\hline \multicolumn{5}{|l|}{ Maternal age (years) } & \multirow{5}{*}{$<0.001$} \\
\hline$<20$ & 749 & 16.1 & 320 & 23.0 & \\
\hline 20 to 34 & 3,557 & 76.5 & 979 & 70.1 & \\
\hline 35 and more & 343 & 7.4 & 97 & 6.9 & \\
\hline $\begin{array}{l}\text { Not known } \\
\text { Marital status }\end{array}$ & 49 & (1.0) & 3 & $(0.2)$ & \\
\hline \multicolumn{5}{|l|}{ M arital status } & \multirow[t]{4}{*}{$<0.001$} \\
\hline $\begin{array}{l}\text { Non-cohabiting } \\
\text { Cohabiting }\end{array}$ & 355 & 7.6 & 200 & 14.8 & \\
\hline $\begin{array}{l}\text { Cohabiting } \\
\text { Not known }\end{array}$ & 4,287 & 92.4 & 1,151 & 85.2 & \\
\hline $\begin{array}{l}\text { Not known } \\
\text { Parity }\end{array}$ & 56 & $(1.2)$ & 48 & $(3.4)$ & \\
\hline \multicolumn{5}{|l|}{ Parity } & \multirow[t]{4}{*}{$<0.001$} \\
\hline$\frac{1}{2}$ to 4 & $\begin{array}{l}1,454 \\
2,360\end{array}$ & 32.0 & 461 & $\begin{array}{l}33.2 \\
547\end{array}$ & \\
\hline 5 and more & $\begin{array}{r}2,300 \\
733\end{array}$ & $\begin{array}{l}01.9 \\
16.1\end{array}$ & 168 & 34.1 & \\
\hline Not known & 151 & $(3.2)$ & 10 & $(0.7)$ & \\
\hline \multicolumn{5}{|l|}{ Preterm birth } & \multirow{4}{*}{$<0.001$} \\
\hline No & 3,150 & 91.4 & 932 & 86.1 & \\
\hline Yes & 297 & 8.6 & 151 & 13.9 & \\
\hline Not known & 1,251 & (26.6) & 316 & (22.6) & \\
\hline \multicolumn{5}{|l|}{ Prenatal visits } & \multirow[t]{3}{*}{$<0.001$} \\
\hline $\begin{array}{l}<4 \\
4\end{array}$ and more & 1,138 & 27.7 & 191 & 14.8 & \\
\hline $\begin{array}{l}4 \text { and more } \\
\text { N ot known }\end{array}$ & $\begin{array}{r}2,963 \\
507\end{array}$ & $\begin{array}{l}72.3 \\
(12.7)\end{array}$ & 1,101 & 85.2 & \\
\hline \multicolumn{5}{|l|}{ Type of insurance } & \multirow{4}{*}{$<0.001$} \\
\hline Private & 340 & 7.3 & 240 & 17.8 & \\
\hline Public & 4,329 & 92.7 & 1,106 & 82.2 & \\
\hline Not known & 29 & $(0.6)$ & 53 & (3.8) & \\
\hline \multicolumn{5}{|l|}{ Maternal smoking status } & \multirow[t]{4}{*}{$<0.001$} \\
\hline No & 3,135 & 69.7 & 1,037 & 80.1 & \\
\hline Yes & 1,363 & 30.3 & 257 & 19.9 & \\
\hline Not known & 200 & $(4.3)$ & 105 & $(7.5)$ & \\
\hline \multicolumn{5}{|l|}{ Maternal schooling (years) } & \multirow[t]{4}{*}{$<0.001$} \\
\hline$<4$ & 1,251 & 27.6 & 279 & 21.7 & \\
\hline 4 to 11 & 2,937 & 64.6 & 924 & 71.8 & \\
\hline $\begin{array}{l}12 \text { and more } \\
\text { Not known }\end{array}$ & 355 & $\begin{array}{l}7.8 \\
(3.3)\end{array}$ & 84 & 6.5 & \\
\hline \multirow{2}{*}{\multicolumn{5}{|c|}{$\begin{array}{l}\text { Family income } \\
<4 \text { minimum wages }\end{array}$}} & $<0.001$ \\
\hline & 2,431 & 65.0 & 535 & 55.0 & \\
\hline 4 to 10 & & 26.0 & 313 & 32.2 & \\
\hline$>10$ minimum wages & 338 & 9.0 & 125 & 12.8 & \\
\hline Not known & 958 & (20.4) & 426 & (30.5) & \\
\hline Occupation groups & & & & & 0.001 \\
\hline Non-manual & 622 & 14.3 & 163 & 12.3 & \\
\hline Skilled/semi-skilled & 2,663 & 61.3 & 823 & 61.8 & \\
\hline Unskilled & 1,059 & 24.4 & 344 & 25.9 & \\
\hline Not known & 354 & (7.5) & 69 & $(4.9)$ & \\
\hline
\end{tabular}

*P-value for difference between surveys (chi-square test)

was demonstrated that the LBW rate increased over a period of 15 years also for those infants whose mothers had vaginal delivery, even though some risk factors for LBW decreased in the same period. Accentuated increases were detected in the percentage of young, non-cohabiting mothers and preterm births.

This increasing trend in LBW rate among vaginal deliveries seems to be largely attributable to a rise in the preterm birth rate and the percentage of non-cohabiting mothers. A further support to this evidence was that, when a separate model for 1994 was fitted, only these two risk factors remained associated with LBW. Despite the increase in the proportion of teen mothers, young maternal age did not contribute to this trend. These findings were also supported by others (Eriksson et al, ${ }^{7} 1997$ ).
Although better qualified families had the lowest proportion of non-cohabiting mothers and preterm birth in both cohorts, they revealed the highest increase in the proportion of non-cohabiting women and preterm birth between 1978-79 and 1994 (data not shown). The higher increase in the proportion of preterm births and non-cohabiting mothers among better-off families partially explains the more accentuated reduction observed in their newborns' mean birth weight. Another possibility is that the increase in LBW and the drop in mean birth weight among vaginal deliveries is in part an artifact caused by a shift from vaginal to cesarean section delivery in the city. Better-off families mothers tended to undergo cesarean section more frequently in 1994 compared to 15 years ago (Gomes et al, ${ }^{8}$ 1999). Vaginal deliv- 
Table 3 - Variables associated with low birth weight among women who had vaginal delivery* in Ribeirão Preto, Brazil, 1978/79 and 1994.

\begin{tabular}{|c|c|c|c|c|c|}
\hline Variable & Total & $n$ & $\%$ & OR $(95 \% \mathrm{Cl})$ & P-value \\
\hline $\begin{array}{l}\text { Gender } \\
\text { Male } \\
\text { Female }\end{array}$ & $\begin{array}{l}3,109 \\
2,982\end{array}$ & $\begin{array}{l}222 \\
282\end{array}$ & $\begin{array}{l}7.1 \\
9.5\end{array}$ & $1.42(1.00)$ & 0.0011 \\
\hline $\begin{array}{l}\text { Marital status } \\
\text { Cohabiting } \\
\text { N on-cohabiting }\end{array}$ & $\begin{array}{r}5,438 \\
555\end{array}$ & $\begin{array}{r}411 \\
85\end{array}$ & $\begin{array}{r}7.6 \\
15.3\end{array}$ & $1.39(1.002-1.90)$ & 0.0357 \\
\hline $\begin{array}{l}\text { Prenatal visits } \\
4 \text { and more } \\
<4 \\
\text { N ot known }\end{array}$ & $\begin{array}{r}4,064 \\
1,329 \\
704\end{array}$ & $\begin{array}{r}271 \\
177 \\
56\end{array}$ & $\begin{array}{r}6.7 \\
13.3 \\
8.0\end{array}$ & $\begin{array}{c}1.00 \\
1.60(1.26-2.04) \\
0.64(0.39-1.06)\end{array}$ & $<0.001$ \\
\hline $\begin{array}{l}\text { Parity } \\
\qquad \begin{array}{l}2 \\
1 \\
1 \\
5\end{array} \text { and more }\end{array}$ & $\begin{array}{r}3,120 \\
1,915 \\
901\end{array}$ & $\begin{array}{r}230 \\
179 \\
76\end{array}$ & $\begin{array}{l}7.4 \\
9.3 \\
8.4\end{array}$ & $\begin{array}{c}1.00 \\
1.37(1.08-1.73) \\
0.93(0.68-1.27)\end{array}$ & 0.0176 \\
\hline $\begin{array}{l}\text { Maternal schooling (years) } \\
12 \text { and more } \\
4 \text { to } 11 \\
<4 \\
\text { N ot known }\end{array}$ & $\begin{array}{r}439 \\
3,861 \\
1,530 \\
267\end{array}$ & $\begin{array}{r}16 \\
309 \\
147 \\
32\end{array}$ & $\begin{array}{r}3.6 \\
8.0 \\
9.6 \\
12.0\end{array}$ & $\begin{array}{c}1.00 \\
2.17(1.18-4.00) \\
2.44(1.28-4.63) \\
1.82(0.66-4.99)\end{array}$ & 0.0551 \\
\hline $\begin{array}{l}\text { Maternal smoking } \\
\text { No } \\
\text { Yes }\end{array}$ & $\begin{array}{l}4,172 \\
1,620\end{array}$ & $\begin{array}{l}258 \\
195\end{array}$ & $\begin{array}{r}6.2 \\
12.0\end{array}$ & $\begin{array}{c}1.00 \\
2.08(1.68-2.59)\end{array}$ & $<0.001$ \\
\hline
\end{tabular}

*M odel excluding values for those variables with few missing data. Reduced model obtained after backward elimination adjusted for all variables shown in this table.

Table 4 - Crude and sequentially adjusted year effect for low birth weight among vaginal deliveries. Ribeirão Preto, Brazil, 1978/79 and 1994.

$$
\text { Variables }
$$

Adjusted only for survey factor

Survey factor plus preterm birth

Above factors plus maternal smoking

Above factors plus parity

Above factors plus non-cohabitation

Above factors plus gender

Above factors plus maternal schooling

Above factors plus prenatal visits

OR $(95 \% \mathrm{Cl})$

$1.32(1.08-1.62)$

$1.14(0.91-1.42)$

$1.37(1.08-1.73)$

$1.37(1.08-1.73)$

$1.32(1.04-1.67)$

$1.31(1.03-1.66)$

$1.33(1.04-1.69)$

$1.40(1.09-1.79)$

ery newborns in 1994 represented a selected cohort of poorer families with poor obstetric and neonatal outcomes. Results of the present study show that, in contrast to the childbearing population as a whole, the percentage of better qualified people and higher schooling decreased among mothers who had vaginal delivery.

The association between cesarean section and LBW tended to cover up socioeconomic differences in the likelihood of LBW. After a restricted analysis based on a selected sample including only vaginal deliveries, mothers with low levels of schooling had a greater risk of LBW. This indicates that socioeconomic differences came up again.

It has been shown that alcohol consumption and illicit drug use are closely related to increased risk of LBW (Brooke et al, ${ }^{5}$ 1989). In Ribeirão Preto, illicit drug use and alcohol consumption are high among teenagers $(8.5 \%$ reported daily use of alcohol and 56.4\% monthly consumption) (Muza et al, ${ }^{13}$ 1997). Alcohol consumption was the same among social classes but illicit drug use was higher among better-off teenagers (Muza et al, ${ }^{14}$ 1997). The highest illicit drug use among better-off teenage mothers could play a role in the more marked decrease in mean birth weight among newborns of better-off mothers. Other potential causes that may explain this phenomenon, such as psychosocial stress, occupational hazards, deterioration of the health services quality in the city, genital infectious or iatrogenic practices associated with childbirth care, were not studied here.

There is some evidence regarding low quality of perinatal care in Brazil. The neonatal death rate, especially within the first 6 days of life, is decreasing very slowly. The reasons for this remain poorly understood. In the State of Rio de Janeiro, it has been shown that neonatal deaths due to respiratory ailments of the fetus and newborn are increasing and the causes of death said to be reducible by "adequate pregnancy monitoring and delivery care" and "early diagnosis and treatment" remain unchanged (Leal \& Szwarcwald, ${ }^{12}$ 1996).

The increasing use of ultrasound-based estimates of gestational age was one of the factors associated with an increase in the preterm birth rate in Canada (Kramer et al, ${ }^{11}$ 1998). Despite the fact that there was an increase in ultrasound-based estimates of gestational age between these two decades, in this study the last menstrual period was used to assess gestational age. So, increasing frequency of ultrasound examination was not a factor in Ribeirão Preto. Changes in registration practices, resulting in a shift from stillbirths to live births at early gestational ages, 
have not affected the estimates. To minimize this influence newborns weighing less than 500 grams were excluded from the analysis. Moreover, there was no clear increase in more premature births from the $35^{\text {th }}$ week of gestation downwards.

It remains unclear whether this increasing trend in LBW rate is restricted to Ribeirão Preto. It is not known whether the same occurred in other Brazilian cities. The only information available is from the city of Pelotas, where an increase in LBW rate was also reported, although lower than the one seen in Ribeirão Preto (Horta et al, ${ }^{9}$ 1996).

\section{REFEREN CES}

1. Altman DG, Coles EG. Nomograms for precise determination of birthweight for dates. $\mathrm{Br} J \mathrm{O}$ bstet Gynecol 1980;87:81-6.

2. Barbieri MA, Gomes UA, Barros Filho AA, Bettiol H, Almeida LEA, Silva AA. Saúde perinatal em Ribeirão Preto, SP, Brasil: A questão do método. Cad Saúde Pública 1989;5:376-87.

3. Bettiol H, Barbieri MA, Gomes UA, Andrea M, Goldani $M$, Ribeiro ERO. Saúde perinatal: metodologia e características da população estudada. Rev Saúde Pública 1998;32:18-28.

4. Bettiol H, Rona RJ, Chinn S, Goldani M, Barbieri MA. Factors associated with preterm births in Southeast Brazil: a comparison of two births born 15 years apart. Paediatr Perinat Epidemiol 2000;14:30-8.

5. Brooke OG, Anderson HR, Bland JM, Peacock JL, Stewart CM. Effects on birth weight of smoking, alcohol, caffeine, socioeconomic factors, and psychosocial stress. Br M ed J 1989;298:795-801.

6. Chike-O bi U, David RJ, Coutinho R, Wu S-Y. Birth weight has increased over a generation. Am J Epidemiol 1996;144:563-9.

7. Eriksson M, Cnattingius S, Svärdsudd K, Tibblin G . Factors associated with birth weight in Sweden: the study of men born in 1913. J Epidemiol Community Health 1997;51:19-23.

8. Gomes UA, Silva AAM, Bettiol H, Barbieri MA. Risk factors for the increasing caesarean section rate in Southeast Brazil: a comparison of two birth cohorts, 1978/79 and 1994. Int J Epidemiol 1999;28:687-94.
It seems that factors associated with the increase in LBW rate in Ribeirão Preto are running in two ways. One trend is stronger and acts upon most affluent women, those who predominantly use the private health sector. Malpracticing cesarean section delivery seems to be the most important factor in this population (Gomes et al, ${ }^{8}$ 1999). The other one is weaker and affects socially deprived women assisted by the National Health Service and whose pregnancy is a burden. The present results also point out to the fact that the increase in the proportion of preterm birth and non-cohabiting women plays an important role in the increasing LBW rate among vaginal deliveries.

9. Horta $\mathrm{BL}$, Barros FC, Halpern R, Victora CG. Baixo peso ao nascer em duas coortes de base populacional no Sul do Brasil. Cad Saúde Pública 1996;12 Supl 1:27-31.

10. Kramer MS. Determinants of low birth weight: methodological assessment and meta-analysis. Bull World Health O rgan 1987;65:663-737.

11. Kramer MS, Platt R, Hong Yang, Joseph KS, Wen SW Morin L, et al. Secular trends in preterm birth: a hospital-based cohort study. JAMA 1998;21:1849-54.

12. Leal MC, Szwarcwald CL. Evolução da mortalidade neonatal no Estado do Rio de Janeiro, Brasil (1979-1993): análise por causa segundo grupo de idade e região de residência. Cad Saúde Pública 1996;12:243-52.

13. Muza GM, Bettiol H, Mucillo G, Barbieri MA. Consumo de substâncias psicoativas por adolescentes escolares de Ribeirão Preto, SP (Brasil). I- Prevalência do consumo por sexo, idade e tipo de substância. Rev Saúde Pública $1997 ; 31: 21-9$

14. Muza GM, Bettiol H, Mucillo G, Barbieri MA. Consumo de substâncias psicoativas por adolescentes escolares de Ribeirão Preto, SP (Brasil). II- Distribuição do consumo por classes sociais. Rev Saúde Pública 1997;31:163-70.

15. Silva AAM, Barbieri MA, Gomes UA, Bettiol H. Trends of low birth weight: a comparison of two birth cohorts separated by a 15 year interval in Ribeirão Preto, Brazil. Bull World Health Organ 1998;76:73-84. 